Date of preparation: October 4, 2001 ( $1^{\text {st }}$ manuscript $)$

July 2, 2002 (revised manuscript)

December 12, $2002\left(2^{\text {nd }}\right.$ revision)

January 20, 2003 (Accepted)

Number of text pages: 28 (including references)

Number of tables: 7

Number of figures: 2

\title{
Phosphorus fractions and dynamics in surface earthworm casts under native and improved grasslands in a Colombian savanna Oxisol ${ }^{\mathbb{T}}$
}

\author{
Juan J. Jiménez $^{\mathrm{a}^{*}}$, Alex Cepeda ${ }^{\mathrm{a}}$, Thibaud Decaëns ${ }^{\mathrm{b}}$, Astrid Oberson ${ }^{\mathrm{c}}$, Dennis K. Friesen ${ }^{\mathrm{d}}$ \\ ${ }^{\text {a }}$ Soil and Plant Nutrition Unit. CIAT. P.O. Box 6713, Cali, Colombia \\ ${ }^{\mathrm{b}}$ Laboratoire d'Ecologie. UPRES-EA 1293. UFR Sciences. Université de Rouen. F-76821 Mont Saint Aignan \\ Cedex, France \\ ${ }^{\mathrm{c}}$ ETH, Institute of Plant Sciences. Eschikon, 33. CH-8315. Lindau, Switzerland \\ ${ }^{\mathrm{d}}$ CIMMYT-IFDC, P.O. Box 25171, Nairobi, Kenya
}

* Author for correspondence

Current address (until May 2003):

Land and Water Development Division (AGLL), Room B-701

FAO

Viale Terme di Caracalla - 00100 Rome, Italy.

E-mail: juan.jimenez@fao.org

II This paper is dedicated to Paulo César Cepeda Virviescas in memoriam.

\section{Abstract}

The objective of this study was to assess the effect of a native anecic species on phosphorus availability in an Oxisol characterised by a low chemical fertility. Experiments were carried out at Carimagua research station in a representative site of the isohyperthermic savannas on 
the Colombian Orinoco basin. One field study and two laboratory/incubation studies were performed in a natural herbaceous savanna and a Brachiaria decumbens and Pueraria phaseoloides pasture. In the laboratory, experiment pots were prepared containing soil collected from the respective field paddock's topsoil. Total P content was higher in earthworm casts than in the surrounding soil in field samples, $50 \%$ in native savanna soil and more than $100 \%$ in pasture soil. In casts produced under laboratory conditions this increase was relatively low (10-20\%). Under field conditions, almost without exception, all P fractions were increased in casts relative to the original soil (corresponding to the increase in total $\mathrm{P}$ content), being relatively greater in the labile inorganic $\mathrm{P}$ fractions. In addition, samples from the natural savanna showed that $\mathrm{pH}$ of casts was higher (5.2) than that of soil (4.6) in both field and laboratory samples. Except in the native savanna under field conditions, the phosphatase activity was reduced in casts by 16.7 to $44 \%$. From our results we conclude that earthworms in the field incorporate $\mathrm{P}$ from litter or other organic sources (i.e. undecomposed plant and root material, earthworm faeces) which is not normally measured in the analysis of bulk soil.

Keywords: Earthworms; Phosphorus; Earthworm casts; Ecosystem engineers; Savanna; Oxisols; Grasslands.

\section{Introduction}

At present there is increasing evidence that soil macroinvertebrates improve soil fertility due to their role in soil organic matter transformations and nutrient dynamics at different spatial and temporal scales, which may improve nutrient uptake by plants (Lavelle, 1997). A few of these invertebrates have been defined as the "soil ecosystem engineers" (Stork and Eggleton, 1992; Jones et al., 1994; Lavelle, 1997). By definition, ecosystem engineers are "those 
organisms that directly or indirectly modulate the availability of resources to other species by causing physical state changes in biotic or abiotic materials" (Jones et al., 1994). This means that they are capable of regulating the trophic (organic matter) and spatial distribution (habitat availability) of resources in the soil through the production of physical bio-structures (e.g. casts, galleries and nests). Soil invertebrates are major determinants of soil processes, especially in tropical ecosystems (Lavelle, 2000).

Earthworms belong to this functional group because through their burrowing activities, mixing soil with litter and egesting casts inside the soil or at the soil surface, they affect the physical properties of soils, nutrient cycling and plant dynamics (Lal, 1991; Thompson et al., 1993; Lavelle, 1997). To assess the contribution of these organisms to soil processes and ecosystem function, it is necessary to describe the phenomena that occur in the casts (Martin and Marinissen, 1993). Yet the impact on nutrient cycling has not been investigated in detail in tropical anecic earthworms (Decaëns et al., 1999b), even though they produce a substantial amount of casts in the soil surface. For example, some studies have revealed higher contents of available phosphorous $(\mathrm{P})$ (that can be taken up by plants) in earthworm casts than in the control soil (Lunt and Jacobson, 1944; Nye, 1955; Lal, 1974;

Krishnamoorthy, 1990; Guggenberger et al., 1996). Effects of earthworms on P are especially interesting since part of the pool, which is normally adsorbed onto the soil solid phase, may be desorbed after gut transit (López-Hernández et al., 1993; Brossard et al., 1996). These organisms have a marked impact on mineralisation of $\mathrm{P}^{\delta}$ (Sharpley and Syers, 1976; James, 1991; López-Hernández et al., 1993; Chapuis and Brossard, 1995; Brossard et al., 1996), and are able to increase its availability for plants in their casts. This process has been widely documented for both tropical and temperate species (Sharpley and Syers, 1976;

\footnotetext{
${ }^{\delta}$ Phosphorus mineralization is an enzymatic process and a group of phosphatases are involved in the catalysis and release of phosphate from organic P compounds to the soil solution (Mullen 1998).
} 
Barois et al., 1987; Lavelle and Martin, 1992; Lavelle et al., 1992; López-Hernández et al., 1993; Scheu, 1987). It is the result of their highly efficient digestive system while they excrete intestinal and cutaneous mucus that leaves nutrients in excess. As a consequence, earthworms have an important role in nutrient availability and cycling in natural and agricultural ecosystems (Coleman et al., 1994; Buse, 1990; Marinissen and de Ruiter, 1993; Bohlen et al., 1997; Decaëns et al., 1999b).

About $75 \%$ of soils in Neotropical savannas are strongly weathered, acidic and infertile belonging to the order of Oxisols (USDA Soil Taxonomy 1978). Low total and available P contents and high $\mathrm{P}$ fixation capacity due to high contents of $\mathrm{Fe}$ and $\mathrm{Al}$ oxides characterise these soils. Only $20 \%$ of total fertilizer P applied to soils in these agroecosystems is recovered by the crop to which it is applied (Friesen et al., 1997). The remainder is gradually rendered less available to succeeding crops by processes that slowly move P into more stable inorganic and organic pools in the soil. One strategy to increase the productivity and sustainability of production in such agroecosystems is to increase P recovery from these less accessible forms using crop and forage cultivars that are more efficient in acquiring $\mathrm{P}$ and cycling it into pools more available to crops. In addition, the role of soil macroinvertebrates in P cycling must be considered for their potential and availability of soil P for plant uptake, since the activities of soil organisms may preserve nutrients in the biostructures they produce and hence reduce the availability to plants in short temporal scales.

The potential of the Colombian savannas, an isohyperthermic ecosystem dominated by Oxisols, for both crop and livestock production systems, is limited by the lack of available $\mathrm{P}$ for primary production (Thomas et al., 1995). The conversion of native savanna into intensive pastures generally leads to a huge increase in earthworm biomass (Decaëns et al., 1994, Jiménez et al., 1998b). Martiodrilus carimaguensis (Glossoscolecidae) is a large anecic 
native savanna earthworm from the Colombian "Llanos" (Jiménez et al., 1998a, b) which has been shown to affect soil processes (Decaëns, 2000; Decaëns et al., 1999a, b) and there is potential to take advantage of its activities in tropical agroecosystems (Mariani, 2001).

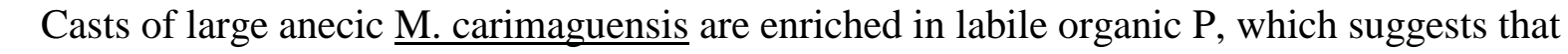
this species improves the supply of $\mathrm{P}$ in soil under pastures by creating an available organic P pool (Guggenberger et al., 1996). Oberson et al. (1999) presented evidence from soil P fractionation analyses which indicated that a high level of $\mathrm{P}$ cycling in intensive pastures contributed to their sustainability with very low $\mathrm{P}$ inputs. Based on these observations, we hypothesized that $\underline{\text { M. carimaguensis, }}$, through greatly increased population density and their effect on soil P dynamics, is a major contributor to the sustainable productivity of intensive pastures on Colombian savannas Oxisols. The objective of this study was to determine the temporal dynamics of $\mathrm{P}$ fractions in casts and quantify $\mathrm{P}$ availability and enhanced $\mathrm{P}$ cycling in an Oxisol of the Colombian Llanos. The study was carried out in both laboratory and field experiments to assess the impact of this species of high casting surface activity (Jiménez et al., 1998a, b; Decaëns et al., 1999b) in nutrient cycling. Since earthworms can accelerate the mineralisation of organic matter by reducing the size of residues to particles more available to microbes (Swift et al., 1979; James, 1991) one laboratory experiment examined the effect of incorporating finely ground vegetative material on P mineralization.

\section{Materials and methods}

\subsection{Study site}

This study was conducted during May-September 1994 at the CIAT-CORPOICA experimental station at Carimagua ( $4^{\circ} 30^{`} \mathrm{~N} ; 71^{\circ} 19^{\prime} \mathrm{W} ; 150 \mathrm{~m}$ above sea level) located 320 $\mathrm{km}$ east of Villavicencio in the Eastern Plains of Colombia. The site is representative of the 
well-drained isohyperthermic savanna ecosystem. Mean annual rainfall and temperature are 2,240 $\mathrm{mm}$ and $26.5^{\circ} \mathrm{C}$ respectively. Rainfall distribution is characterized by a 4-month sharp dry season from December to March. Native vegetation varies with topography accordingly: open herbaceous savannas in the uplands ("altos"), and gallery forests or flooding savannas in the low-lying areas ("bajos”). Samplings were done in a well-drained silt-clay Oxisol (typic haplustox, fine kaolinitic, isohyperthermic). They are characterised by favourable physical properties, e.g. porosity and water retention, but high $\mathrm{Al}$ saturation $(>80 \%)$ and low chemical fertility (Table 1).

\subsection{Background ecology of $\underline{\mathrm{M} . \text { carimaguensis }}$}

Martiodrilus carimaguensis is a large native dorsally pigmented earthworm quite common in the savannas of Carimagua (Colombia). The dimensions for adults are $9.3 \mathrm{~mm}$ in diameter, $194 \mathrm{~mm}$ in length and weighs $9.2 \mathrm{~g}$ (in 4\% formalin) on average (Jiménez et al., 1998a). Its morphology and life history traits are like most anecic species (sensu Bouché, 1977); however, it only eats litter in an opportunistic way and its feeding regime is mostly based on small casts egested by other earthworm species (Mariani et al., 2001). The establishment of intensive pastures results in a spectacular increase of density compared to the native savanna, 18.2 and 0.2 ind $\mathrm{m}^{-2}$, respectively (Jiménez et al., 1998b). The main aspects of their biology, ecology and adaptive strategies can be consulted in Jiménez and Decaëns (2000) and Jiménez et al. (1999; 2000).

\subsection{Casts of $\underline{\mathrm{M} \text {. carimaguensis }}$}


1 Martiodrilus carimaguensis produces a substantial amount of tower-like casts at the soil

2 surface. Their size range from 3 to $6 \mathrm{~cm}$ in diameter, 2 to $10 \mathrm{~cm}$ in height and $25 \mathrm{~g}$ dry

3 weight on average (Decaëns, 2000). As they are deposited the casts are a pasty structure, and

4 within a period of days, the final structure is a combination of dry and fresh material at the

5 bottom and the top of the cast, respectively. Whether the earthworm leaves its semi-

6 permanent burrow or descends deep in the soil to begin diapause (Jiménez et al., 2000) the

7 cast dries completely, and may remain at the soil surface for more than one year (Decaëns,

8 2000). The disappearance of casts from the soil surface are both of environmental and

9 anthropogenic origin, i.e. rainfall impacts, fire, vegetation cover, cattle trampling and the

10 burrowing by small invertebrates (Decaëns, 2000; Mariani et al., in press).

\subsection{Experimental design}

Three experiments were performed during the rainy season of 1994: one field study and two laboratory/incubation studies using soils from the same plots (paddocks) where the fieldwork was conducted.

\subsubsection{Field experiment}

The field experiment was carried out from May to August in two nearby land use systems

19 (paddocks). They were a 2.3 ha. herbaceous native savanna dominated by Andropogon bicornis L. and Trachypogon vestitus Anders. that was burnt the previous year, and a $18 \mathrm{yr}-$ old 2-ha. grazed pasture of Brachiaria decumbens $\mathrm{cv}$ Basilisk and Pueraria phaseoloides (Roxb.) Benth. CIAT 9900 (Kudzu). The pasture was grazed by 1 cattle ha $^{-1}$ during the dry season and 2 cattle $\mathrm{ha}^{-1}$ during the rainy period. 
1 A randomized block-design was used. In each paddock, nine areas of $4 \times 4$ and $1 \times 1 \mathrm{~m}^{2}$, respectively, were randomly allocated and, in the case of the pasture, these were protected with wire exclusion cages to avoid cattle trampling and physical disturbance of surface casts. The difference in the size of these areas was due to the fact that outstanding differences regarding earthworm numbers existed and therefore in the number of surface casts (Jiménez et al., 1998a). In each land use system (paddock) the nine sampling areas were randomly grouped in clusters containing three areas. The surface casts were sampled from each area and included within each group, so that there were three replicates for each sampling date. Hence, a replicate was considered as the sum of casts collected from the three randomly selected areas.

The surface casts that were already present in the sampling areas were removed the day before the experiment started, and on the following day, fresh surface casts recently deposited were identified, and displaced aside the earthworm gallery. Casts were tagged with a plastic peg to identify the time of in situ incubation that corresponded to six different ages, i.e. $1,4,8,16,32$ and 64 days after they were egested in the soil surface. In order to ensure enough cast material for a given incubation time, casts were picked up, placed in an ice chest and carried to the laboratory. $70 \mathrm{~g}$ of fresh casts were collected approximately for each group, of which $40 \mathrm{~g}$ were dried under forced draft in an oven at $40{ }^{\circ} \mathrm{C}$ and $30 \mathrm{~g}$ were stored in a refrigerator at $4{ }^{\circ} \mathrm{C}$ prior to analysis as described below.

Control soil samples were taken in each paddock by splitting it into four areas where five 0$15 \mathrm{~cm}$ soil cores were taken per area and mixed. Samples were further prepared for analyses by crushing and sieving through a 2-mm mesh. Samples for microbial P determinations were maintained fresh under refrigeration as mentioned above. 


\subsubsection{Laboratory experiments}

Two laboratory experiments were conducted. In the first (LE1), no additional treatment other than the soil from the paddocks was applied. In the second (LE2), two additional treatments were applied in factorial combination with the two field treatments, e.g. green vegetative material collected from the same land use systems was added to one of the treatments. In order to test the effect of plant material addition on $\mathrm{P}$ dynamics the vegetative material was oven-dried, finely ground and mixed with the corresponding soil at a rate of $20 \mathrm{~g} \mathrm{~kg}^{-1}$ soil. A first set of twelve pots were prepared using $6 \mathrm{~kg}$ of soil (air-dried and sieved to $2 \mathrm{~mm}$ ) collected from the top $15 \mathrm{~cm}$ of the two land use systems where the fieldwork was conducted, although not in the same replicate areas used in the field study. These twelve pots corresponded to the land use systems studied, savanna and introduced pasture, two treatments (with and without organic amendments) and three replicates. The moisture content of the soil was adjusted to $\mathrm{pF} 2\left(25 \% \mathrm{H}_{2} \mathrm{O} v / \mathrm{v}\right)$ in each pot 5 days prior to earthworm introduction. Twelve adults of $\underline{\mathrm{M} \text {. carimaguensis }}$ were collected in the field and placed in each pot for a 6-day period of conditioning to void field-ingested material. Afterwards, earthworms were transferred directly to another set of pots [12 units that corresponded to land use system (2), addition of plant material (2) and three replicates] containing 2-kg of the same sieved and similarly preconditioned soil. These pots were used only to collect cast material. After 1 day, these second pots were examined, casts retrieved and earthworms from each pot were moved to another set of pots prepared in an identical manner to ensure that casts belonged to the same experimental unit. This procedure was repeated six times to complete the temporal lag, i.e. 1, 4, 8, 16, 32, 64 days of cast incubation and to ensure the same conditions for cast sorting. Surface cast material from the pots was placed in Petri dishes containing moistened filter paper in order to maintain the humidity of casts. These 
were incubated at ambient temperature $\left(24 \pm 3{ }^{\circ} \mathrm{C}\right)$ in the laboratory for the same time periods, after which they were broken up, mixed and separated into two other samples (one air dried, and the other moist) as described above for the field experiment. Control (noningested) soil was sampled from pots when earthworms were introduced and treated in the same manner as the incubated casts.

\subsection{Determination of soil P fractions in casts and controls}

Phosphorous in soil and earthworm casts were fractionated according to a modified method of Hedley et al. (1982) using successively the following increasingly aggressive extractants: $\mathrm{H}_{2} \mathrm{O}$ with anion exchange resin in $\mathrm{HCO}_{3}^{-}$form, $0.5 M \mathrm{NaHCO}_{3}, 0.1 M \mathrm{NaOH}, 1 M \mathrm{HCl}$, and hot concentrated $\mathrm{HCl}$ (Tiessen and Moir, 1993). Inorganic P in extracts was determined by the molybdate-ascorbic acid method (Murphy and Riley, 1962). Total P in the $\mathrm{H}_{2} \mathrm{O}, \mathrm{NaHCO}_{3}$ and $\mathrm{NaOH}$ was measured after digestion with $\mathrm{K}_{2} \mathrm{~S}_{2} \mathrm{O}_{8}$ (Bowman, 1988). Total soil $\mathrm{P}$ was determined by perchloric acid digestion (Olsen and Sommers, 1982). Controls and one dayold casts were fractionated according to the full method while a reduced method using the first three extractants was applied to the remaining samples.

Inorganic P removed by anion exchange resin comes either from solution or is desorbed from the $\mathrm{Al}$ and $\mathrm{Fe}$ oxyhydroxide colloid surfaces in the soil (Mattlingly, 1975). Sodium bicarbonate (0.5 M at pH 8.5) also extracts weakly adsorbed $\mathrm{P}_{\mathrm{i}}$ (Hedley et al., 1982). Together these two $P_{i}$ fractions constitute a highly available $P_{i}$ pool in soil. More slowly available $\mathrm{P}_{\mathrm{i}}$ (also called "secondary $\mathrm{P}_{\mathrm{i}}$ ") is extracted by $0.5 \mathrm{M} \mathrm{NaOH}$ and is associated with amorphous and crystalline $\mathrm{Fe}$ and $\mathrm{Al}$ oxyhydroxides. Highly labile soluble organic $\mathrm{P}$ compounds are found in the water phase of the resin- $\mathrm{H}_{2} \mathrm{O}$ extractant. The weakly alkaline $\mathrm{NaHCO}_{3}$ extractant also removes easily hydrolyzable organic $\mathrm{P}\left(\mathrm{P}_{\mathrm{o}}\right)$ compounds such as 
ribonucleic acids and glycerophosphate (Bowman and Cole, 1978) while the more strongly alkaline $\mathrm{NaOH}$ solution extracts less labile $\mathrm{P}_{\mathrm{o}}$ associated with fulvic and humic acids. Dilute $\mathrm{HCl}(0.1 \mathrm{M})$ extracts $\mathrm{P}_{\mathrm{i}}$ from apatite or octocalcium phosphate (Frossard et al., 1995), neither of which are likely to be present in Oxisols unless they have been fertilized with phosphate rocks. Hot concentrated $\mathrm{HCl}$ extracts more stable pools of $\mathrm{P}_{\mathrm{i}}$ and $\mathrm{P}_{\mathrm{o}}$, some of which may be associated with particulate organic matter (Tiessen and Moir, 1993). The P remaining in the sample (residual $\mathrm{Pt}$ ) contains very recalcitrant $\mathrm{P}_{\mathrm{i}}$ and $\mathrm{P}_{\mathrm{o}}$ forms that likely participate in $\mathrm{P}$ cycling processes only at long term.

Phosphorus in the microbial biomass and acid soil phosphatase activity were estimated on moist samples using procedures described by Oberson et al. (1999) and Tabatabai (1982), respectively. This procedure was used since air drying of cast and soil samples may cause loss of inorganic P from microbial biomass and give erroneous results (Sparling et al., 1985; James, 1991).

Total carbon and nitrogen were analyzed on previously $2 \mathrm{~mm}$ sieved subsamples. A LECO CR-12 furnace with $\mathrm{CO}_{2}$ infrared detection was used to determine total $\mathrm{C}$, and the standard Kjeldahl digestion to measure total $\mathrm{N}$ contents (Krom, 1980). A titration method was used to extract exchangeable $\mathrm{Al}$ and $\mathrm{H}$ using $1 \mathrm{M} \mathrm{KCl}$. Cations were extracted with $1 M \mathrm{NH} 4-$ acetate and determined by atomic absorption spectrometry using standard methods.

\subsection{Statistical analysis}

The Kolmogorov-Smirnov test (Lilliefors, 1967) was used to test the normality of data distribution, and transform data before analysis if necessary. A two-way analysis of variance (ANOVA) was performed with land use (savanna / pasture) and sample origin (cast vs. soil) as the fixed main effects for phosphatase activity, microbial $\mathrm{P}$, total $\mathrm{P}$, total $\mathrm{C}, \mathrm{Bray}-\mathrm{II} \mathrm{P}$ and 
$1 \mathrm{pH}$ (water, 1:1). To analyse the differences on the $\mathrm{P}$ fractions extracted with $\mathrm{H}_{2} \mathrm{O} /$ resin,

2 bicarbonate and $\mathrm{NaOH}$ solutions for each sampling date a two-way ANOVA with again land

3 use and cast age as the fixed main effects was used. The Bonferroni procedure for multiple

4 nested tests was applied (Cooper, 1968) to adjust the significance probability levels. The

5 adjusted $0.05,0.01$ and 0.001 levels were, respectively: 0.004 [= $0.05 /(2 \times 6)], 0.0008$ [=

$6 \quad 0.01 /(2 \times 6)]$, and $8.310^{-5}[=0.001 /(2 \times 6)]$. Additional comparisons of means were

7 performed with the Tukey HSD test for all variables when the F-test was significant $(P<$

8 0.05). The software package Statistica 5.1 for Windows (C Statsoft Inc. 1996) was used in

$9 \quad$ all statistical analyses.

\section{Results}

3.1. Phosphatase activity, microbial $\mathrm{P}$, total $\mathrm{P}$, and other chemical properties

Phosphatase activity in soils and casts ranged from 120 to $313 \mathrm{mg}$-nitrophenol $\mathrm{kg}^{-1} \mathrm{~h}^{-1}$ in laboratory experiment samples, and from 249 to $312 \mathrm{mg}$-nitrophenol $\mathrm{kg}^{-1} \mathrm{~h}^{-1}$ in the in-situ (field collected) pasture and savanna samples, respectively. Except for in-situ samples from soil (Table 2), probably due to the manipulation of soil or because enzymes were partly degraded during gut transit or because phosphates production was decreased due to higher availability of $\mathrm{P}$ in casts. In field samples, phosphatase activity was higher in earthworm casts than in soil in the native savanna system but lower in the intensive pasture, although these differences were not significant the interaction of fixed main effects was significant in 1-day-old casts than in the corresponding control soil from the savanna and from the 
1 pasture (Table 3). Values of $\mathrm{pH}$ were significantly higher in earthworm casts than in the control soil in both systems and for both field and laboratory produced samples.

Total P content was significantly higher in 1-day old earthworm casts than in control soil for both laboratory incubated and field aged samples (Tables 2 and 3). Total P calculated from the sum of $\mathrm{P}$ fractions did not differ significantly from that determined directly by perchloric acid digestion for any particular treatment (not shown). In the laboratory experiments, casts contained 10-20 mg- $\mathrm{P} \mathrm{kg}^{-1}$ soil or 5-10\% more total $\mathrm{P}$ than the soil from which they were produced. Casts produced in the field had approximately 1.5 and 2 fold more $\mathrm{P}$ than the bulk soil in the native savanna and the introduced pasture, respectively (Table 2).

Bray-II P and total C concentrations were significantly higher in 1-day-old casts than in the corresponding control soil for field samples in both systems (Table 3), while no significant differences were observed for the laboratory samples (Table 2).

\subsection{P dynamics}

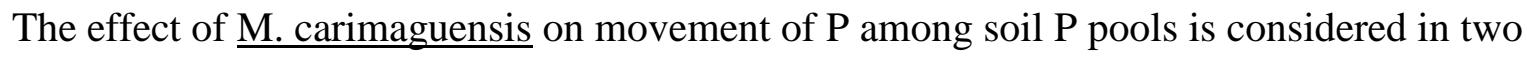
phases, the first being the immediate effect of transit through the earthworm's gut and the second being the subsequent temporal changes in $\mathrm{P}$ concentration in pools as the deposited cast is aged in situ in the field or incubated in the laboratory.

The immediate effects of casting on the concentration of $\mathrm{P}$ in soil $\mathrm{P}$ pools in the field and laboratory are shown in Tables 4 and 5, respectively. Under field conditions, almost without exception $\mathrm{P}$ fractions were larger in casts than in the bulk soil (corresponding to the increase in total $\mathrm{P}$ content). Increases ranged from $0 \%\left(\mathrm{HClhc}-\mathrm{P}_{\mathrm{o}}\right)$ to $875 \%\left(\right.$ Resin- $\left.\mathrm{P}_{\mathrm{i}}\right)$ in the egested savanna soil and $46 \%$ (Residue $\mathrm{Pt})$ to $814 \%\left(\right.$ Resin- $\left.\mathrm{P}_{\mathrm{i}}\right)$ in the egested pasture soil, and were relatively greater in the labile $\mathrm{P}_{\mathrm{i}}$ fractions (resin- $\mathrm{P}_{\mathrm{i}}$ and $\mathrm{NaHCO}_{3}-\mathrm{P}_{\mathrm{i}}$ ) than in the other $\mathrm{P}$ 
1 fractions. In both savanna and pasture derived casts, about $60 \%$ of the increased $\mathrm{P}$ content was found in $\mathrm{P}_{\mathrm{i}}$ fractions, $30 \%$ in $\mathrm{P}_{\mathrm{o}}$ fractions and $10 \%$ in the residual $\mathrm{P}_{\mathrm{t}}$ fraction. Most of the total $\mathrm{P}$ increase in cast over soil was found in secondary $(\mathrm{NaOH}) \mathrm{P}_{\mathrm{i}}$ and $\mathrm{P}_{\mathrm{o}}$ pools in both savanna and pasture derived casts, with significant amounts entering stable $\mathrm{P}$ pools as well, especially in the pasture casts.

Under laboratory conditions where the increase in total P content due to casting (11-17\%) was much smaller than in the field, increases in the sizes of $\mathrm{P}$ fractions ranged from $0 \%$ to $344 \%$ (Table 5). In the savanna soil casts, most of the added $\mathrm{P}$ was found in the secondary $\mathrm{P}$ pools $\left(20 \% \mathrm{NaOH}-\mathrm{P}_{\mathrm{i}}\right.$ and $\left.64 \% \mathrm{NaOH}-\mathrm{P}_{\mathrm{o}}\right)$ whereas substantial amounts were also found in the stable $\mathrm{P}$ and residual Pt pools in the pasture soil casts. The addition of green material residues had no significant effect on either $\mathrm{P}_{\mathrm{i}}$ or $\mathrm{P}_{\mathrm{o}}$ fractions in the laboratory experiment, neither in the soil nor in the casts.

The dynamics of labile pools of $\mathrm{P}$ in ageing casts is shown in Figures 1 and 2 for laboratory and field incubation experiments, respectively. The statistical significance of the fixed main effects and their interaction is shown in tables 6 and 7 for casts incubated in the field and in the laboratory, respectively. In most cases the interaction of cast age and land use was not significant, except for the $\mathrm{P}_{\mathrm{i}}$ extracted by $\mathrm{NaOH}$ and bicarbonate in casts incubated in the field. $\mathrm{P}_{\mathrm{i}}$ extracted by resin was increased strongly in fresh casts but then slowly declined to the levels in soil over the following 64 days of incubation. In contrast, organic P extracted by bicarbonate and hydroxide increased 1 to 8 days after casting, rather than during transit of the earthworm gut, and then remained relatively constant over the remaining 56 days of the incubation. Inorganic P in bicarbonate and hydroxide was not affected significantly by casting and did not change significantly with time of incubation. 
1 Similar patterns in $\mathrm{P}$ dynamics in $\mathrm{P}_{\mathrm{i}}$ and $\mathrm{P}_{\mathrm{o}}$ fractions were observed during in situ ageing of

2 M. carimaguensis casts produced in the field although of much lower magnitude, especially

3 for Po fractions. The most marked changes occurred during transit of the earthworm gut

4 whereas, after the initial increase, $\mathrm{P}_{\mathrm{i}}$ and $\mathrm{P}_{\mathrm{o}}$ in all fractions remained relatively constant over 5 the 64 days of field incubation.

\section{Discussion}

4.1. $\mathrm{P}$ accumulation and mineralization in casts

The use of both field and laboratory experiments in this study helps provide a better understanding of the actual dynamics of nutrients in soil and in biogenic structures produced by soil macroinvertebrates. Although the total P contents of control soils in the field and laboratory experiments were similar, ingestion by $\underline{\mathrm{M}}$. carimaguensis increased total $\mathrm{P}$ by $53 \%$ to $114 \%$ under field conditions but by $<20 \%$ under laboratory conditions. Under field

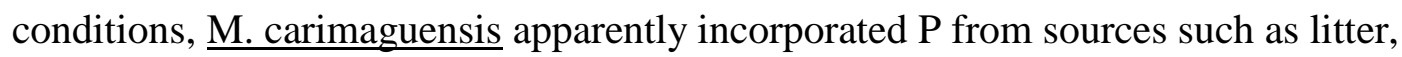
undecomposed plant debris and roots and other holorganic casts that were not present in the soil under laboratory conditions. Together with mixing of soil and litter, both coprophagy and necro-rhizophagy seem to be the dominant features of the $\underline{\mathrm{M}}$. carimaguensis diet (Mariani et al., 2001).

Phosphorus incorporated into soil from "non-soil" sources may enter into all P fractions (organic and inorganic) but the fractionation data indicate that a greater proportion entered into labile $\mathrm{P}_{\mathrm{i}}$ fractions, particularly under field conditions (Tables 4 and 5). It is not possible to conclude that $\underline{\mathrm{M} \text {. carimaguensis }}$ promoted the mineralization of organic $\mathrm{P}$ since the proportion of $\mathrm{P}$ fractions in the substrate was unknown. However, the fact that under laboratory conditions, where organic litter substrate was not provided (LE1) and where the 
increase in total $\mathrm{P}$ due to casting was quite small, relatively large increases especially in the secondary $\left(\mathrm{NaOH}-\mathrm{P}_{\mathrm{i}}\right.$ and $\left.-\mathrm{P}_{\mathrm{o}}\right)$ pool sizes accompanied by decreases in stable fractions suggests that ingestion of the soil by the earthworm did promote movement of $\mathrm{P}$ from stable to more labile $\mathrm{P}$ forms. Moreover, the relatively large increases observed in resin- $\mathrm{P}_{\mathrm{i}}$ in the laboratory experiment, and in all labile fractions $\left(\mathrm{H}_{2} \mathrm{O}-\mathrm{P}_{\mathrm{o}}\right.$, resin- $\mathrm{P}_{\mathrm{i}}$, bic- $\mathrm{P}_{\mathrm{i}}$ and bic- $\left.\mathrm{P}_{\mathrm{o}}\right)$ in the field experiment (all small pools), suggests some mineralization of less available P from large more stable pools where relative changes would be difficult to detect. This would agree with the interpretation that $\underline{\mathrm{M}}$. carimaguensis likely behaves as an endogeic (soil consumer) rather than an anecic (soil + litter consumer) species in terms of feeding regimes (Mariani et al., 2001). Since the addition of green material residues had no significant effect on either $P_{i}$ or $\mathrm{P}_{\mathrm{o}}$ fractions in the casts produced in the laboratory experiment, the hypothesis that $\underline{\mathrm{M}}$. carimaguensis ingests faeces from other earthworms (Mariani et al., 2001) or even may feed on their own casts (Jiménez et al., 1998b) is strengthened.

Although beginning with almost identical total soil P contents, casts produced in situ in the $\underline{B}$. decumbens and $\underline{P}$. phaseoloides pasture had more than twice the total $\mathrm{P}$ content and correspondingly higher P content in all fractions than casts produced from savanna soil (Table 4). This was probably due to higher biomass production, both aboveground and roots, of legume and deep-rooting grasses in the pasture resulting in greater litter fall and root turnover (Thomas, 1992; 1995; Thomas et al., 1992; Oberson et al., 1995; Fisher et al., 1994) as well as dung depositions from cattle.

Our study confirmed the results obtained by several authors who reported higher P contents in earthworm casts than in the surrounding soil from grassland ecosystems (Sharpley and Syers, 1976; Barois and Lavelle, 1986; Barois et al., 1987; James, 1991; López-Hernández et al., 1993; Brossard et al., 1996; Scheu, 1987). Barois et al. (1999) reported a significant increase of available $\mathrm{P}$ after transit through the earthworm gut, with the largest differences 
1 for water extractable $\mathrm{P}$, which was doubled after ingestion. Phosphorus contents were at least

$230 \%$ higher in casts of several earthworm species than in the soil. In our study, water

3 extractable $\mathrm{P}$ was $300 \%$ higher in casts than in the adjacent control soil under field

4 conditions. Stabilization of $\mathrm{P}$ in casts of $\underline{\mathrm{M}}$. carimaguensis occurred between 16 and 64 days

5 after cast deposition, whilst this lag was of 4 days in casts of the endogeic $\underline{P \text {. corethrurus }}$

6 (López-Hernández et al., 1993).

7 Sharpley and Syers (1976) estimated that the total amount of organic-P accumulated in 30

8 tons $\mathrm{ha}^{-1} \mathrm{yr}^{-1}$ of surface earthworm casts in permanent pastures from a New Zealand

9 watershed was 11-14 $\mathrm{kg} \mathrm{ha}^{-1} \mathrm{yr}^{-1}$. Estimated surface fresh cast production by $\underline{\mathrm{M}}$. carimaguensis at the study site was, respectively, $1.2 \mathrm{t} \mathrm{ha}^{-1} \mathrm{yr}^{-1}$ and $13.2 \mathrm{t} \mathrm{ha}^{-1} \mathrm{yr}^{-1}$ in the savanna and in the pasture, based on a density of 0.2 fresh casts $\mathrm{m}^{-2}$ and 2.2 fresh casts $\mathrm{m}^{-2}$ in the respective systems and taken into account the active period of the species, at least 4 months (Jiménez, 1999). The average dry weight of casts ranges from 25 g (Decaëns, 2000) to $35 \mathrm{~g}$ (Jiménez, unpubl. data). Thus, $0.36 \mathrm{~kg} \mathrm{ha}^{-1} \mathrm{yr}^{-1}$ and $5.61 \mathrm{~kg} \mathrm{ha}^{-1} \mathrm{yr}^{-1}$ of total $\mathrm{P}$ may be accumulated in fresh casts of $\underline{\mathrm{M}}$. carimaguensis, respectively, in the savanna and the pasture (0.13 and $1.8 \mathrm{~kg} \mathrm{ha}^{-1} \mathrm{yr}^{-1}$ of total $\mathrm{P}_{\mathrm{o}}$ ). This represents an important contribution to the overall 
1 species in the soil and the casts deposited in the soil (Jiménez et al. 1998a). Thus, our results confirm those of Guggenberger et al. (1996) who showed that earthworm activity at Carimagua resulted in a marked effect on $\mathrm{P}$ availability.

A higher phosphatase activity in savanna soil than in pasture soil may be due to very low $P_{i}$ availability in savanna soil (Oberson et al., 2001), explained by differences in botanical composition of both systems (Rao et al., 1997). Measurements of phosphatase activity and microbial $\mathrm{P}$ on field experiment samples further indicate that $\underline{\mathrm{M} \text {. carimaguensis participates }}$ in the mineralization of available $\mathrm{P}_{\mathrm{o}}$ fractions. In the field experiments, phosphatase activity was greater in $\underline{M}$. carimaguensis casts than in the control soil from the savanna. The conflicting observation seen in the laboratory experiment was probably an artifact of the methodology since the organic residues added to earthworm cultured pots could have already mineralized before ingestion by the earthworms. The high values of phosphatase activity obtained in our study for all treatments show the importance of both biological and biochemical processes in $\mathrm{P}_{\mathrm{o}}$ mineralization (Oberson et al., 1995).

López Hernández et al. (1989) observed no difference in phosphatase activity between termite mounds and surrounding soil in Venezuelan savannas. However, Satchell and Martin (1984) reported high $\mathrm{P}_{\mathrm{i}}$ content in fresh casts due to high phosphatase activity. A strong enzymatic activity has also been reported in fresh earthworm casts from temperate regions (Sharpley and Syers, 1976) as well as tropical sites (Mulongoy and Bedoret, 1989).

Microbial activity is enhanced in casts of tropical earthworms due to strong enzymatic activity and available organic C (Mulongoy and Bedoret, 1989). In this study values of microbial $\mathrm{P}$ were similar in both soil and cast samples from the lab experiment, and slightly higher in samples from the pasture. In summary, therefore, the increase in total P content of casts over soils in the field can be explained by organic matter, litter (including roots) and 
cast selection by $\underline{\mathrm{M} \text {. carimaguensis }}$ while the comparative increases in labile fractions extracted with water, $\mathrm{NaHCO}_{3}$ and $\mathrm{NaOH}$ are due to the reorganization or translocation of $\mathrm{P}$ from stable to available pools for plant uptake. Evidence for the latter is found in the increased microbial biomass $\mathrm{P}$ in casts.

\section{2. "Soil ecosystem engineers" and $\mathrm{P}$ dynamics in savanna soils}

Casts of $\underline{M}$. carimaguensis are large resistant structures that persist at the soil surface from two to eleven months on average in intensive pastures (exposed or protected to cattle trampling, respectively), and 5 months in native savannas (Decaëns, 2000). Some termite species (Nasutitermitinae) colonize these compact casts and create channels and deposit faecal pellets over its surface. When these casts finally split and smaller aggregates spread in the soil surface, the nutrients that were preserved from further mineralization processes may be released (Decaëns, 2000). Thus these surface casts represent a significant source of direct P easily available for plant uptake and may also explain the increase in root biomass observed under earthworm casts (Decaëns et al., 1999a). The role of other soil ecosystem engineers present in these savannas on $\mathrm{P}$ dynamics via the biogenic structures they create, for

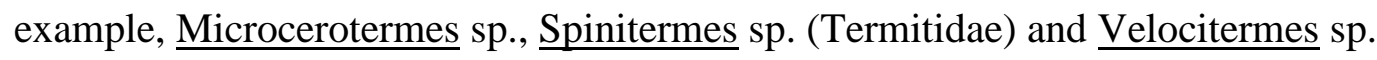

(Nasutitermitinae) species and the ants Atta laevigata and Acromyrmex landolti (Decaëns et al., 2001) should be addressed in further studies.

The importance of $\underline{M}$. carimaguensis activity in natural and introduced pastures on incorporating $\mathrm{P}$ from organic sources into soil $\mathrm{P}$ pools, in increasing the labile $\mathrm{P}$ pools and improving P cycling was demonstrated in our short-term studies under laboratory and field conditions. The ecological significance of earthworms in P cycling in the native savanna and the introduced pasture is based on the improved nutritional basis of plant litter from the 
1 pasture. There is an enhancement of biotic processes in the pasture, since populations of this species are quite large (Jiménez et al., 1998b) and there is also higher microbial biomass $\mathrm{P}$ (Oberson et al., 2001). The long-term effects of earthworms on P cycling and other nutrients must therefore be tremendous and merit further investigation, since the net benefits of earthworms in soil quality improvement and fertility are still ignored.

Studies on the role that soil ecosystem engineers play in P dynamics in Neotropical savannas are restricted to a few. Soil feeding termites can increase available $\mathrm{P}$ in their nests two or five-fold (Anderson and Wood, 1984). In the savannas of Venezuela, for example, both the quantity and distribution of $\mathrm{P}$ depends upon the biological activity of the termite

Nasutitermes ephratae (Holmgren) (Nasutitermitidae) as reported by López-Hernández et al. (1989). The availability of mineral P derived from litter or soil can be increased by the activity of earthworms (Mansell et al., 1981), as we found in the field study. But P availability also changes with time as casts aged in the field. Similarly, Wood et al. (1983) found that $\mathrm{P}$ retention declined in the biogenic structures produced by the African savanna termite Cubitermes oculatus.

\section{Acknowledgements}

We thank the staff at Carimagua station for their friendship and invaluable help during field work, G. Borrero and M. Rodríguez (CIAT) for their technical assistance with the phosphorus fractionations. We are grateful to I. Rao (CIAT), P. Lavelle (IRD, France) and M. Brossard (IRD-EMBRAPA Brazil) for their comments, criticism and useful recommendations made on a previous version of this manuscript. Thanks to $\mathrm{R}$. Thomas (CIAT) for English revision. Andrés F. Rangel is acknowledged for his help during fieldwork while doing his own research and A. Feijoo for his comments and support given to 
one of the coauthors. We are also deeply appreciated to two anonymous referees for their suggestions that helped us improve this article.

\section{References}

Anderson, J.M., Wood, T.G., 1984. Mound composition and soil modification by two soilfeeding termites (Termitinae, Termitidae) in a riparian Nigerian forest. Pedobiologia 26, 7782.

Barois, I., Lavelle, P., 1986. Changes in respiration rates and some physicochemical properties of a tropical soil during transit through Pontoscolex corethrurus (Glossoscolecidae, Oligochaeta). Soil Biology \& Biochemistry 18, 539-541.

Barois, I., Lavelle, P., Brossard, M., Tondoh, J., Martínez, M.A., Rossi, J.P., Senapati, B.K., Angeles, A., Fragoso, C., Jiménez, J.J., Decaëns, T., Lattaud, C., Kanyonyo, J., Blanchart, E., Chapuis, L., Brown, G.G., Moreno, A., 1999. Ecology of earthworm species with large environmental tolerance and/or extended distributions. In: Lavelle, P., Brussaard, L., Hendrix, P.F. (Eds.), Earthworm Management in Tropical Agroecosystems. CAB-I, Wallingford, pp. 57-85.

Barois, I., Verdier, B., Kaiser, P., Lavelle, P., Rangel, P., 1987. Influence of the tropical earthworm Pontoscolex corethrurus (Glossoscolecidae)on the fixation and mineralization of nitrogen. In : Bovincini Pagliai, A. M., Omodeo, P. (Eds.), On Earthworms, Vol. 2. Selected Sympsia and Monographs, U.Z.I., Ed. Mucchi, Modena, pp. 151-158.

Bohlen, P.J., Parmelee, R.W., McCartney, D.A., Edwards, C.A., 1997. Earthworm effectts on Carbon and Nitrogen dynamics of surface litter in corn agroecosystems. Ecological Applications 7(4), 1341-1349.

Bouché, M.B., 1977. Stratégies lombriciennes. In: Lohm, U., Persson, T. (Eds.), Soil Organisms as Component of Ecosystems. Ecol. Bull. (Stockholm) 25, 122-132.

Bowman R.A., 1988. A rapid method to determine total phosporous in soils. Soil Science Society of America Journal 52, 1301-1304. 
1 Bowman R.A., Cole, C., 1978. An exploratory method for fractionation of organic phosphorous from grassland soils. Soil Science 125, 95-100.

Brossard, M., Lavelle, P., Laurent, J.Y., 1996. Digestion of a vertisol by the endogeic earthworm (Polypheretima elongata, Megascolecidae) increases soil phosphate extractability. European Journal of Soil Biology 32, 107-111.

Buse, A., 1990. Influence of earthworms on nitrogen fluxes and plant growth in cores taken from variously managed upland pastures. Soil Biology \& Biochemistry 22 (6), 775-780.

Chapuis, L., Brossard, M., 1995. Modifications et stabilité du phosphore échangeable d'un ferrasol ingere par un ver géophage. Compte Rendus de l'Académie des Sciences de Paris Series IIa 320, 587-592.

Coleman, D.C., Hendrix, P.F., Beare, M.H., Crossley, D.A., Hu, S., van Vliet, P.C.J., 1994. The impacts of management and biota on nutrient dynamics and soil structure in sub-tropical agroecosystems: Impacts on detritus food webs. In: Pankhurst, C.E., Doube, B.M., Gupta, V.V.S.R., Grace, P.R. (Eds.), Soil Biota. Management in Sustainable Farming Systems. CSIRO, Melbourne, pp. 133-143.

Cooper, D.W., 1968. The significance level in multiple tests made simultaneously. Heredity 23, 614-617.

Decaëns, T., 2000. Degradation dynamics of surface earthworm casts in grasslands of the eastern plains of Colombia. Biology and Fertility of Soils 32, 149-156.

Decaëns, T., Galvis, J.H., Amézquita, E., 2001. Propriétés des structures produites par les ingénieurs écologiques à la surface du sol d'une savane colombienne. Compte Rendus de 1'Academie des Sciences de Paris Série III 324(5), pp. 465-478.

Decaëns, T., Lavelle, P., Jiménez, J.J., Escobar, G., Rippstein, G., 1994., Impact of land management on soil macrofauna in the Oriental Llanos of Colombia. European Journal of Soil Biology 30(4), 157-168. 
1 Decaëns, T., Mariani, L., Lavelle, P., 1999a. Soil surface macrofaunal communities associated with earthworm casts in grasslands of the Eastern Plains of Colombia. Applied Soil Ecology 13, 87-100.

Decaëns, T., Rangel, A.F., Asakawa, N., Thomas, R.J., Lavelle, P., 1999b. Carbon and nitrogen dynamics in ageing earthworm casts in grasslands of the Eastern plains of Colombia. Biology \& Fertility of Soils 30, 20-28.

Fisher, M.J., Rao, I.M., Ayarza, M.A., Lascano, C.E., Sanz, J.I. , Thomas, R.J. and Vera, R.R., 1994. Carbon storage by deep-rooted grasses in the Southamerican savannas. Nature 371, 236-238.

Friesen, D.K., Rao, I.M., Thomas, R.J., Oberson, A., Sanz, J.I., 1997. Phosphorous acquisition and cycling in crop and pasture systems in low fertility tropical soils. Plant \& Soil 196, 289-294.

Frossard, E., Brossard, M., Hedley, M. J., Metherel, A., 1995. Reactions controlling the cycling of P in soils. In: Tiessen, H. (Ed.), Phosphorus in the Global Environment. John Wiley and Sons, New York.

Guggenberger, G., Haumaier, L., Thomas, R.J., Zech, W., 1996. Assesing the organic phosphorous status of an Oxisol under tropical pastures following native savanna using ${ }^{31} \mathrm{P}$ NMR spectroscopy. Biology \& Fertility of Soils 23, 332-339.

Hedley, M.J., Stewart, J.W.B., Chauhan, B.S., 1982. Changes in inorganic and organic soil phosphorous fractions induced by cultivation practices and by laboratory incubations. Soil Science Society of America Journal 46, 970-976.

James, S.W. 1991. Soil, nitrogen, phosphorous and organic matter processing by earthworms in tallgrass prairie. Ecology 72(6), 2101-2109.

Jiménez, J.J., 1999. Estructura de las Comunidades y Dinámica de las Poblaciones de Lombrices de Tierra en las Sabanas Naturales y Perturbadas de Carimagua (Colombia). Doctoral Thesis, Universidad Complutense, Madrid, 311 p (in Spanish). 
1 Jiménez, J.J., Decaëns, T., 2000. Vertical distribution of earthworms in grassland soils of the

2 Colombian Llanos. Biology \& Fertility of Soils 32, 463-473.

3 Jiménez, J.J., Moreno, A.G., Lavelle, P., 1999. Reproductive strategies of three native

4 earthworm species from the savannas of Carimagua (Colombia). Pedobiologia 43, 851-858.

5 Jiménez, J.J., Moreno, A.G., Lavelle, P., Decaëns, T., 1998a. Population dynamics and

6 adaptive strategies of Martiodrilus carimaguensis (Oligochaeta, Glossoscolecidae), a native

7 species from the well-drained savannas of Colombia. Applied Soil Ecology 9 (1-3), 153-160.

8 Jiménez, J.J., Brown, G.G., Decaëns, T., Feijoo, A., Lavelle, P., 2000. Differences in the timing

9 of diapause and patterns of aestivation in some tropical earthworms. Pedobiologia 44(6), 677-

10694.

11 Jiménez, J.J., Moreno, A.G., Decaëns, T., Lavelle, P., Fisher, M.J., Thomas, R.J., 1998b.

12 Earthworm communities in native savanna and man-made pastures of the eastern plains of

13 Colombia. Biology \& Fertility of Soils 28, 101-110.

14 Jones, C.G., Lawton, J.H., Shachak, M., 1994. Organisms as ecosystem engineers. Oikos 69, $15 \quad 373-386$.

Krishnamoorthy, R.V., 1990. Mineralization of phosphorous by faecal phosphatases of some earthworms of Indian tropics. Proceedings of the Indian Academie of Sciences (Animal Sciences) 95, 341-351.

Krom, M., 1980. Spectrophotometric determination of ammonia, a study of modified

Bertheloy reaction using salicylate and dichloroisocyanurate. Analyst 105, 305-316.

Lal, R., 1974. No tillage effects on soil properties and maize (Zea mays L.) production in western Nigeria. Plant \& Soil, 40: 321-331.

Lal, R., 1991. Soil conservation and biodiversity. In: Hawksworth, D.L. (Ed.), The Biodiversity of Microrganisms and Invertebrates: Its Role in Sustainable Agriculture. CAB International, Wallingford, pp. 89-103. 
1 Lavelle, P., 1997. Faunal activities and soil processes: adaptive strategies that determine ecosystem function. Advances in Ecological Research 27, 93-132

3 Lavelle, P., 2000. Ecological challenges for soil science. Soil Science 165, 73-86.

4 Lavelle, P., Martin, A., 1992. Small-scale and large-scale effects of endogeic earthworms on 5 soil organic matter dynamics in soils of the humid tropics. Soil Biology \& Biochemistry 6 24(12), 1491-1498.

7 Lavelle, P., Blanchart, E., Martin, A., Spain, A.V., Martin, S., 1992. Impact of soil fauna on the 8 properties of soils in the humid tropics. In: Segoe, S. (Ed.), Myths and Science of Soils of the 9 Tropics. SSSA Special Publication No. 29, Madison, pp. 157-185.

10 Lilliefors, H.W., 1967. The Kolmogorov-Smirnov test for normality with mean and variance unknown. Journal of American Statistical Association 62, 399-402. transformations in two P-sorption contrasting tropical soils during transit through Pontoscolex corethrurus (Glossoscolecidae: Oligochaeta). Soil Biology \& Biochemistry 25 (6), 789-792.

López-Hernández, D., Fardeau, J.C., Niño, M., Nannipieri, P., Chacón, P., 1989.

Phosphorous accumulation in savanna termite mound in Venezuela. Journal of Soil Science 40, 635-640.

Lunt, H.A., Jacobson, G.M., 1944. The chemical composition of earthworm casts. Soil Science 58, 367-375.

Mansell, G.P., Syers, J.K., Gregg P.E.H., 1981. Plant availability of phosphorous in dead herbage ingested by surface-casting earthworms. Soil Biology \& Biochemistry 13, 163-167.

Mariani, L., 2001. Impact des biostructures produites par Martiodrilus carimaguensis (Oligochaeta, Glossoscolecidae) sur le fonctionnement du sol dans les savannes orientales de Colombie. Thèse de Doctorat. Université Pierre et Marie Curie, Paris VI. 236p. (in French). 
1 Mariani, L., Bernier, N., Jiménez, J.J. and Decaëns, T., 2001. Régime alimentarie d'un ver de terre des savanes colombiennes - une remise en question des types écologiques. Compte Rendus de l'Academie des Sciences de Paris Série III, 324(8): 733-742.

Mariani, L., Decaëns, T., Jiménez, J.J., Torres, E.A., Amézquita, E., Rainfall impact on casts of various ages of a tropical anecic earthworm. Geoderma (in press).

Marinissen, J.C.Y., de Ruiter P.C., 1993. Contribution of earthworms to carbon and nitrogen cycling in agroecosystems. Agriculture Ecosystems and Environment 47, 59-74.

Martin, A., Marinissen, J.Y.C., 1993. Biological and physico-chemical processes in excrements of soil animals. Geoderma 56, 331-347.

Mattlingly, G.E.G., 1975. Labile phosphate in soil. Soil Science 119, 369-375.

Mullen, M.D., 1998. Transformations of other elements. In: Sylvia, D.M., Fuhrmann, J.J., Hartel, P.G., Zuberer, D.A. (Eds.), Principles and Applications of Soil Microbiology. Prentice Hall, New Jersey, pp. 369-386.

Mulongoy, K., Bedoret, A., 1989. Properties of worm casts and surface soils under various plant covers in the humid tropics. Soil Biology \&Biochemistry 21, 197-203.

Murphy, J., Riley, J.P., 1962. A modified single solution method for the determination of phosphate in natural waters. Anal Chim Acta 27, 31-36.

Nye, P.H., 1955. Some soil-forming processes in the humid tropics. IV. The action of soil fauna. Journal of Soil Science 6(1), 73-83.

Oberson, A., Friesen, D.K., Rao, I.M., Bühler, S., Frossard, E., 2001. Phosphorous transformations in an oxisol under contrasting land-use systems: the role of the soil microbial biomass. Plant \& Soil 237, 197-210.

Oberson, A., Friesen, D.K., Tiessen, H., Moir, J.O. and Borrero, G., 1995. Phosphorus transformations in improved pastures, In: Tropical Lowlands Program Annual Report 1994. Working document no. 148. CIAT, Cali, Colombia, pp. 182-187. 
1 Oberson, A., Friesen, D.K., Tiessen, H., Morel, C., Stahel, W., 1999. Phosphorus status and

2 cycling in native savanna and improved pastures on an acid low-P Colombian Oxisol.

3 Nutrient Cycling in Agroecosystems 55(1), 77-88.

4 Olsen, S.R., Sommers, L.E., 1982. Phosphorous. In: Page, A.L., Miller, R.H., Keeney, D.R.

5 (Eds.), Methods of Soil Analysis, part 2, $2^{\text {nd }}$ ed. ASA, Madison, Wisconsin, pp. 404-430.

6 Satchell, J.E., Martin, K., 1984. Phosphatase activity in earthworm faeces. Soil Biology \& 7 Biochemistry 16, 191-194.

8 Rao, I.M., Borrero, V., Ricaurte, J., García, R., Ayarza, M.A., 1997. Adaptive attributes of

9 tropical forage species to acid soils III. Differences in phosphorus acquisition and utilization

10 as influenced by varying phosphorus supply and soil type. Journal of Plant Nutrition 20, 15511180.

Scheu, S., 1987. Microbial activity and nutrient dynamics in earthworm casts (Lumbricidae). Biology \& Fertility of Soils 5, 230-234.

Sharpley, A.N., Syers, J.K., 1976. Potential role of earthworm casts for the Phosphorous enrichment of run-off waters. Soil Biology \& Biochemistry 8, 341-346.

Sparling, G.P., Whale, K.N., Ramsay, A.J., 1985. Quantifying the contribution from the soil microbial biomass to the extractable P levels of fresh and acid air-dried soils. Australian Journal of Soil Research 23, 613-621.

Stork, N.E., Eggleton, P., 1992. Invertebrates as determinants and indicators of soil quality. American Journal of Alternative Agriculture 7, 38-47.

Swift, M.J., Heal, O.W., Anderson, J.M., 1979. Decomposition in Terrestrial Ecosystems. Blackwell Scientific, Oxford.

Tabatabai, M.A., 1982. Soil enzymes. In: Page, A.L., Miller, R.H., Keeney, D.R. (Eds.), Methods of Soil Analysis, part 2. Chemical and Microbiological properties. ASA and SSSA publication, Madison, Wisconsin, pp. 903-947. 
1 Thomas, R.J., Lascano, C., Sanz, J.I., Ara, M.A., Spain, J.M., Vera, R.R., Fisher, M.J., 1992.

2 The role of pastures in production systems. In: CIAT. Pastures for the Tropical Lowlands.

3 CIAT's Contributions. Cali, Colombia, pp. 121-144.

4 Thomas, R.J., 1992. The role of the legume in the nitrogen cycle of productive and

5 sustainable pastures. Grass and Forage Science 47, 133-142.

6 Thomas, R.J., 1995. Role of legumes in providing $\mathrm{N}$ for sustainable tropical pasture systems.

$7 \quad$ Plant \& Soil 174, 103-118.

8 Thomas, R.J., Fisher, M.J., Ayarza, M.A., Sanz, J.I., 1995. The role of forage grasses and 9 legumes in maintaining the productivity of acid soils in Latin America. In: Lal, R., Stewart, 10 B.A. (Eds.), Soil Management: Experimental Basis for Sustainability and Environmental 11 Quality. Advances in Soil Science series. Lewis Publishers, Boca Raton, pp. 61-83. Thompson, L., Thomas, C.D., Radley, J.M.A., Williamson, S., Lawton, J.H., 1993. The effect of earthworms and snails in a simple plant community. Oecologia 95, 171-178. Tiessen, H., Moir, J.O., 1993. Characterization of avalilable P by sequential extraction. In: Carter, M.R. (Ed.), Soil Sampling and Methods of Analysis. Lewis Publishers, Boca Raton, FL, USA. pp. 75-86.

Wood, T.G., Johnson, R.A., Anderson, J.M., 1983. Modification of soils in Nigerian savanna by soil feeding Cubitermes (Isoptera, Termitidae). Soil Biology \& Biochemistry 15, 575-579. 


\section{Tables}

2

3 Table 1. Physico-chemical properties of soils in the native savanna and the intensive pasture ${ }^{\dagger}$

\begin{tabular}{|c|c|c|c|c|c|c|c|c|c|}
\hline \multirow{2}{*}{$\begin{array}{l}\text { Land use } \\
\text { system }\end{array}$} & \multirow{2}{*}{$\begin{array}{c}\mathrm{pH}\left(\mathrm{H}_{2} \mathrm{O}\right) \\
1: 1\end{array}$} & \multirow{2}{*}{ Total C } & \multirow{2}{*}{ Total N } & \multirow{2}{*}{ Bray-II P } & \multicolumn{5}{|c|}{ Exchangeable cations } \\
\hline & & & & & $\mathrm{Al}$ & $\mathrm{Ca}$ & $\mathrm{Mg}$ & $\mathrm{K}$ & $\mathrm{H}$ \\
\hline & & \multicolumn{3}{|c|}{$\ldots \ldots \operatorname{mg~g}^{-1} \ldots \ldots$} & \multicolumn{5}{|c|}{$\ldots$} \\
\hline Savanna & 4.80 & 23.5 & 1.45 & 1.3 & 2.42 & 0.26 & 0.11 & 0.08 & 0.27 \\
\hline Pasture & 4.96 & 24.9 & 1.67 & 2.2 & 1.90 & 0.89 & 0.23 & 0.09 & 0.26 \\
\hline
\end{tabular}

4

${ }^{\dagger}$ Oberson et al. (1999) 
Table 2. Chemical properties (mean \pm standard error) of soil and one day-old casts of $\underline{\mathrm{M}}$. carimaguensis in the 2 laboratory (LE1 experiment) and field experiments.

\begin{tabular}{lllllll}
\hline Experiment & $\mathrm{pH}\left(\mathrm{H}_{2} \mathrm{O}\right)$ & $\begin{array}{l}\text { Total C } \\
(\%)\end{array}$ & $\begin{array}{l}\text { Bray-II P } \\
\left(\mathrm{mg}-\mathrm{P} \mathrm{kg}^{-1}\right)\end{array}$ & $\begin{array}{l}\text { Phosphatase } \\
\text { activity } \\
\left(\mathrm{mg} \mathrm{kg}^{-1} \mathrm{~h}^{-1}\right)^{\S}\end{array}$ & $\begin{array}{l}\text { Microbial P } \\
\left(\mathrm{mg}^{-} \mathrm{P} \mathrm{kg}^{-1}\right)\end{array}$ & $\begin{array}{l}\text { Total P } \\
\left(\mathrm{HClO}_{4} \text { dig. }\right) \\
\left(\mathrm{mg} \mathrm{kg}^{-1}\right)\end{array}$
\end{tabular}

\section{Laboratory Experiment}

Native savanna

$\begin{array}{lllllll}\text { Soil } & 4.6 \pm 0.01 & 2.6 \pm 0.04 & 2.6 \pm 0.19 & 215 \pm 13.5 & 4.1 \pm 0.07 & 208 \pm 0.88 \\ \text { Casts } & 5.2 \pm 0.02 & 2.5 \pm 0.00 & 2.9 \pm 0.13 & 120 \pm 10.1 & 4.1 \pm 0.44 & 225 \pm 4.06\end{array}$

B. decumbens - Kudzu pasture

$\begin{array}{lllllll}\text { Soil } & 4.6 \pm 0.01 & 2.9 \pm 0.02 & 4.2 \pm 0.20 & 313 \pm 16.6 & 6.0 \pm 0.52 & 248 \pm 0.33 \\ \text { Casts } & 5.2 \pm 0.05 & 3.0 \pm 0.04 & 4.1 \pm 0.65 & 242 \pm 6.63 & 5.4 \pm 0.24 & 272 \pm 0.67\end{array}$

Field Experiment

Native savanna

$\begin{array}{lllllll}\text { Soil } & 5.1 \pm 0.04 & 2.1 \pm 0.02 & 1.0 \pm 0.06 & 254 \pm 7.46 & 2.5 \pm 0.13 & 179 \pm 1.42 \\ \text { Casts } & 5.4 \pm 0.04 & 4.1 \pm 0.03 & 6.3 \pm 0.25 & 312 \pm 4.2 & 4.0 \pm 0.34 & 267 \pm 5.92\end{array}$

B. decumbens - Kudzu pasture

$\begin{array}{lllllll}\text { Soil } & 5.2 \pm 0.05 & 2.1 \pm 0.04 & 2.5 \pm 0.20 & 299 \pm 6.89 & 4.1 \pm 0.67 & 194 \pm 2.65 \\ \text { Casts } & 5.8 \pm 0.65 & 5.2 \pm 0.11 & 11.0 \pm 0.92 & 249 \pm 7.13 & 10.9 \pm 0.88 & 396 \pm 28.06\end{array}$

\footnotetext{
$3{ }^{\S} \mathrm{mg} \rho$-nitrophenol kg-1 $\mathrm{h}^{-1}$

$4 \$$ from laboratory experiment 2 (LE2)

5
} 
1 Table 3. Two-way analyses of variance (ANOVA) for phosphatase activity, microbial biomass $\mathrm{P}, \mathrm{pH}$, Bray-II P, Total P and Total C in soil and one day-old casts of $\mathrm{M}$.

2 carimaguensis from incubation in the field. The F-ratios and error mean squares for each variable are indicated. Each test is significant at the Bonferroni corrected probability 3 level [overall probability / $\mathrm{n}$ of variable $\mathrm{x}$ of tests)] for overall significant levels of $0.05,0.01$, and 0.001 . $^{\mathrm{a}}$

\begin{tabular}{|c|c|c|c|c|c|c|c|}
\hline Source & $d f$ & $\begin{array}{l}\text { Phosphatase } \\
\text { activity }^{\text {b }}\end{array}$ & Microbial $\mathrm{P}^{\mathrm{b}}$ & $\mathrm{pH}^{\mathrm{b}}$ & Bray-II P & Total $\mathrm{P}^{\mathrm{c}}$ & Total $\mathrm{C}^{\mathrm{c}}$ \\
\hline Land use $(\mathrm{A})$ & 1 & $0.02 \mathrm{NS}$ & $44.10 * * *$ & $23.30 * *$ & $94.58 * * *$ & $40.43 * * *$ & $62.65 * * *$ \\
\hline Cast vs. soil (B) & 1 & $0.17 \mathrm{NS}$ & $48.47 * * *$ & $100.64 * * *$ & $551.91 * * *$ & $272.90 * * *$ & $2595.10 * * *$ \\
\hline $\mathrm{AxB}$ & 1 & $54.72 * * *$ & $9.14 \mathrm{NS}$ & $5.14 \mathrm{NS}$ & $0.28 \mathrm{NS}$ & $20.25 * * *$ & $71.57 * * *$ \\
\hline Error mean squares & $10^{\mathrm{b}}, 24^{\mathrm{c}}$ & 0.00044 & 0.0048 & 0.00004 & 0.0037 & 0.0014 & 0.00018 \\
\hline
\end{tabular}

$5 \quad{ }^{\mathrm{a}} \mathrm{NS}=$ not significant; $* P<0.05 ; * * P<0.01 ; * * * P<0.001$. 


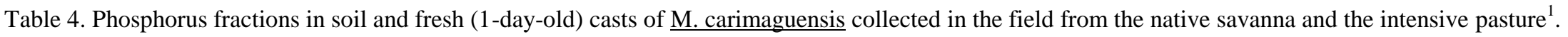

\begin{tabular}{|c|c|c|c|c|c|c|c|c|c|c|c|c|c|c|}
\hline & & \multirow{2}{*}{$\mathrm{H}_{2} \mathrm{O}-\mathrm{Po}$} & \multirow{2}{*}{ Resin-Pi } & \multicolumn{2}{|c|}{$\mathrm{NaHCO}_{3}$} & \multicolumn{2}{|c|}{$\mathrm{NaOH}$} & \multirow{2}{*}{$\begin{array}{c}1 M \mathrm{HCl}- \\
\mathrm{Pi}\end{array}$} & \multicolumn{2}{|c|}{$\mathrm{HCl}$ hc } & \multirow{2}{*}{$\begin{array}{c}\text { Residue } \\
\text {-Pt }\end{array}$} & \multirow{2}{*}{$\begin{array}{l}\text { Total } \\
\text { Pi }\end{array}$} & \multirow{2}{*}{$\begin{array}{c}\text { Total } \\
\text { Po }\end{array}$} & \multirow{2}{*}{$\begin{array}{c}\text { Total } \\
\mathrm{P}\end{array}$} \\
\hline & & & & $\mathrm{Pi}$ & Po & $\mathrm{Pi}$ & Po & & $\mathrm{Pi}$ & Po & & & & \\
\hline \multirow[t]{4}{*}{ Savanna } & Soil & $0.5 \mathrm{~b}$ & $0.8 \mathrm{~b}$ & $1.6 \mathrm{c}$ & $8.6 \mathrm{~b}$ & $22 \mathrm{bc}$ & $42 \mathrm{ac}$ & $0.3 \mathrm{~b}$ & $38 \mathrm{c}$ & $22 \mathrm{ac}$ & $59 \mathrm{~b}$ & 63 & $73 \mathrm{~b}$ & $195 \mathrm{c}$ \\
\hline & Cast & $1.4 \mathrm{a}$ & $7.8 \mathrm{a}$ & $9.9 \mathrm{~b}$ & $17.0 \mathrm{a}$ & $52 \mathrm{ac}$ & $68 \mathrm{a}$ & $0.9 \mathrm{~b}$ & $52 \mathrm{~b}$ & $21 \mathrm{ac}$ & $68 \mathrm{~b}$ & 123 & $108 \mathrm{a}$ & $299 \mathrm{~b}$ \\
\hline & \%increase & 180 & 875 & 519 & 98 & 137 & 64 & 200 & 36 & -5 & 15 & 95 & 47 & 53 \\
\hline & $\% \mathrm{P}$ added $^{2}$ & 1 & 7 & 8 & 8 & 29 & 25 & 1 & 13 & -1 & 9 & 58 & 33 & 100 \\
\hline \multirow[t]{4}{*}{$\frac{\text { B. decumbens }}{+ \text { Kudzu }}$} & Soil & $0.8 \mathrm{~b}$ & $1.4 \mathrm{~b}$ & $2.8 \mathrm{c}$ & $9.1 \mathrm{~b}$ & $26 \mathrm{~b}$ & $43 \mathrm{bc}$ & $0.8 \mathrm{~b}$ & $45 \mathrm{bc}$ & $10 \mathrm{bc}$ & $60 \mathrm{~b}$ & 76 & $62 \mathrm{~b}$ & $199 \mathrm{c}$ \\
\hline & Cast & $2.0 \mathrm{a}$ & $12.8 \mathrm{a}$ & $19.0 \mathrm{a}$ & $18.8 \mathrm{a}$ & $82 \mathrm{a}$ & $82 \mathrm{a}$ & $5.6 \mathrm{a}$ & $83 \mathrm{a}$ & $32 \mathrm{a}$ & $88 \mathrm{a}$ & 202 & $136 \mathrm{a}$ & $425 \mathrm{a}$ \\
\hline & \%increase & 150 & 814 & 579 & 107 & 213 & 92 & 600 & 83 & 234 & 46 & 165 & 117 & 114 \\
\hline & $\% \mathrm{P}$ added & 1 & 5 & 7 & 4 & 25 & 17 & 2 & 17 & 10 & 12 & 56 & 32 & 100 \\
\hline
\end{tabular}

1 values within a column followed by the same letter do not differ significantly $(P<0.05)$ according to Tukey's HSD test.

2 percentage of total $\mathrm{P}$ increase in cast over soil found in respective fraction. 


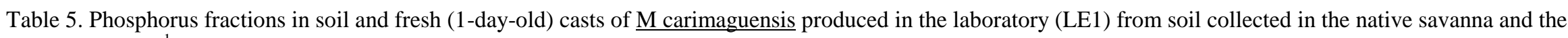
intensive pasture ${ }^{1}$.

\begin{tabular}{|c|c|c|c|c|c|c|c|c|c|c|c|c|c|c|}
\hline & & \multirow{2}{*}{$\mathrm{H}_{2} \mathrm{O}-\mathrm{Po}$} & \multirow{2}{*}{ Resin-Pi } & \multicolumn{2}{|c|}{$\mathrm{NaHCO}_{3}$} & \multicolumn{2}{|c|}{$\mathrm{NaOH}$} & \multirow{2}{*}{$\begin{array}{c}1 M \mathrm{HCl}- \\
\mathrm{Pi}\end{array}$} & \multicolumn{2}{|c|}{$\mathrm{HCl} \mathrm{hc}$} & \multirow{2}{*}{$\begin{array}{c}\text { Residue } \\
-\mathrm{Pt}\end{array}$} & \multirow{2}{*}{$\begin{array}{c}\text { Total } \\
\text { Pi }\end{array}$} & \multirow{2}{*}{$\begin{array}{c}\text { Total } \\
\text { Po }\end{array}$} & \multirow{2}{*}{$\begin{array}{c}\text { Tota } \\
\mathrm{P}\end{array}$} \\
\hline & & & & $\mathrm{Pi}$ & Po & $\mathrm{Pi}$ & Po & & $\mathrm{Pi}$ & Po & & & & \\
\hline \multirow[t]{4}{*}{ Savanna } & Soil & $1.6 \mathrm{ab}$ & $0.9 \mathrm{~d}$ & $4.1 \mathrm{~b}$ & 1.8 & $25 \mathrm{~d}$ & $32 \mathrm{c}$ & 0.3 & $41 \mathrm{~b}$ & 16 & 43 & 71 & $51 \mathrm{bc}$ & $165 \mathrm{~b}$ \\
\hline & Cast & $1.9 \mathrm{~b}$ & $4.0 \mathrm{~b}$ & $4.3 \mathrm{~b}$ & 2.4 & $30 \mathrm{c}$ & $50 \mathrm{~b}$ & 0.4 & $42 \mathrm{~b}$ & 17 & 42 & 81 & $71 \mathrm{ac}$ & $193 \mathrm{bc}$ \\
\hline & \%increase & 19 & 344 & 5 & 33 & 23 & 57 & 33 & 2 & 6 & -3 & 14 & 39 & 17 \\
\hline & $\% \mathrm{P}$ added $^{2}$ & 1 & 11 & 1 & 2 & 20 & 64 & 0 & 2 & 3 & -5 & 35 & 70 & 100 \\
\hline \multirow[t]{4}{*}{$\frac{\text { B. decumbens }}{+ \text { Kudzu }}$} & Soil & $1.7 \mathrm{ab}$ & $2.8 \mathrm{c}$ & $6.5 \mathrm{a}$ & 1.0 & $34 \mathrm{~b}$ & $54 \mathrm{a}$ & 0.2 & $51 \mathrm{a}$ & 22 & 46 & 94 & $78 \mathrm{a}$ & $218 \mathrm{ac}$ \\
\hline & Cast & $2.5 \mathrm{a}$ & $6.3 \mathrm{a}$ & $6.5 \mathrm{a}$ & 1.4 & $39 a$ & $57 \mathrm{a}$ & 0.7 & $55 \mathrm{a}$ & 20 & 55 & 108 & $80 \mathrm{a}$ & $243 \mathrm{a}$ \\
\hline & \%increase & 47 & 125 & 0 & 40 & 14 & 5 & 250 & 9 & -12 & 20 & 14 & 2 & 11 \\
\hline & $\% \mathrm{P}$ added & 3 & 15 & 0 & 2 & 20 & 11 & 2 & 20 & -11 & 38 & 57 & 5 & 100 \\
\hline
\end{tabular}

1 values within a column followed by the same letter (or no letter) do not differ significantly $(P<0.05)$ according to Tukey's HSD test.

${ }^{2}$ percentage of total $\mathrm{P}$ increase in cast over soil found in respective fraction. 
Table 6. Two-way ANOVA for the different P fractions analysed in control soil and incubated casts of $\underline{\mathrm{M}}$. carimaguensis in the field. The F-ratios and error mean squares for each variable are indicated. Each test is significant at the Bonferroni corrected probability level [overall probability / ( $\mathrm{n}$ of variable $\mathrm{x} n$ of tests)] for overall significant levels of $0.05,0.01$, and 0.001 . $^{\mathrm{a}}$

\begin{tabular}{|c|c|c|c|c|c|c|c|}
\hline Source & $d f$ & $\mathrm{H}_{2} \mathrm{O}-\mathrm{P}_{\mathrm{o}}$ & Resin- $P_{i}$ & $\mathrm{NaHCO}_{3}-\mathrm{P}_{\mathrm{o}}$ & $\mathrm{NaHCO}_{3}-\mathrm{P}_{\mathrm{i}}$ & $\mathrm{NaOH}-\mathrm{P}_{\mathrm{o}}$ & $\mathrm{NaOH}-\mathrm{P}_{\mathrm{i}}$ \\
\hline Land use (A) & 1 & $58.65 * * *$ & $87.49 * * *$ & $32.67 * * *$ & $118.81 * * *$ & $37.15 * * *$ & $229.31 * * *$ \\
\hline Cast age (B) & 6 & $17.54 * * *$ & $21.35 * * *$ & $15.23 * * *$ & $32.04 * * *$ & $25.81 * * *$ & $49.98 * * *$ \\
\hline $\mathrm{AxB}$ & 6 & $3.50 \mathrm{NS}$ & $2.89 \mathrm{NS}$ & $2.25 \mathrm{NS}$ & $3.67 *$ & $1.42 \mathrm{NS}$ & $4.30 *$ \\
\hline Error mean squares & 66 & 0.11 & 4.02 & 7.70 & 7.99 & 81.02 & 47.97 \\
\hline
\end{tabular}

${ }^{\mathrm{a}} \mathrm{NS}=$ not significant; $* P<0.05 ; * * P<0.01 ; * * * P<0.001$ 
Table 7. Two-way ANOVA for the different $\mathrm{P}$ fractions analysed in control soil and incubated casts of $\underline{\mathrm{M}}$. carimaguensis in the laboratory. The F-ratios and error mean squares for each variable are indicated. Each test is significant at the Bonferroni corrected probability level [overall probability / ( $\mathrm{n}$ of variable $\mathrm{x} n$ of tests)] for overall significant levels of $0.05,0.01$, and 0.001 . $^{\mathrm{a}}$

\begin{tabular}{|c|c|c|c|c|c|c|c|}
\hline Source & $d f$ & $\mathrm{H}_{2} \mathrm{O}-\mathrm{P}_{\mathrm{o}}$ & Resin- $P_{i}$ & $\mathrm{NaHCO}_{3}-\mathrm{P}_{\mathrm{o}}$ & $\mathrm{NaHCO}_{3}-\mathrm{P}_{\mathrm{i}}$ & $\mathrm{NaOH}-\mathrm{P}_{\mathrm{o}}$ & $\mathrm{NaOH}-\mathrm{P}_{\mathrm{i}}$ \\
\hline Land use (A) & 1 & $9.25 \mathrm{NS}$ & $103.77 * * *$ & $0.18 \mathrm{NS}$ & $13.67 *$ & $2.65 \mathrm{NS}$ & $57.72 * * *$ \\
\hline Cast vs. soil (B) & 6 & $11.50 * * *$ & $22.66 * * *$ & $9.83 * * *$ & $1.15 \mathrm{NS}$ & $1.40 \mathrm{NS}$ & $2.40 \mathrm{NS}$ \\
\hline $\mathrm{AxB}$ & 6 & $0.71 \mathrm{NS}$ & $2.13 \mathrm{NS}$ & $0.65 \mathrm{NS}$ & $1.63 \mathrm{NS}$ & $1.22 \mathrm{NS}$ & $0.93 \mathrm{NS}$ \\
\hline Error mean squares & 66 & 0.15 & 0.27 & 15.98 & 1.72 & 176.32 & 18.99 \\
\hline
\end{tabular}

${ }^{\mathrm{a}} \mathrm{NS}=$ not significant; $* P<0.05 ; * * P<0.01 ; * * * P<0.001$ 


\section{Figure captions}

2

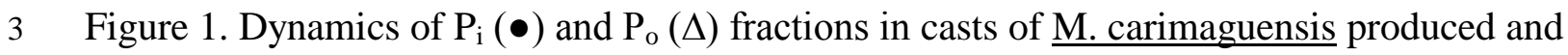
4 incubated in the laboratory (LE1 experiment). $C$ Control (non-ingested) soil. Bars indicate 5 standard deviation.

6

7 Figure 2. Dynamics of $\mathrm{P}_{\mathrm{i}}(\bullet)$ and $\mathrm{P}_{\mathrm{o}}(\Delta)$ fractions in in-situ ageing casts of $\underline{\mathrm{M} \text {. carimaguensis. }}$

$8 \quad C$ Control (non-ingested) soil. Bars indicate standard deviation.

9

10 


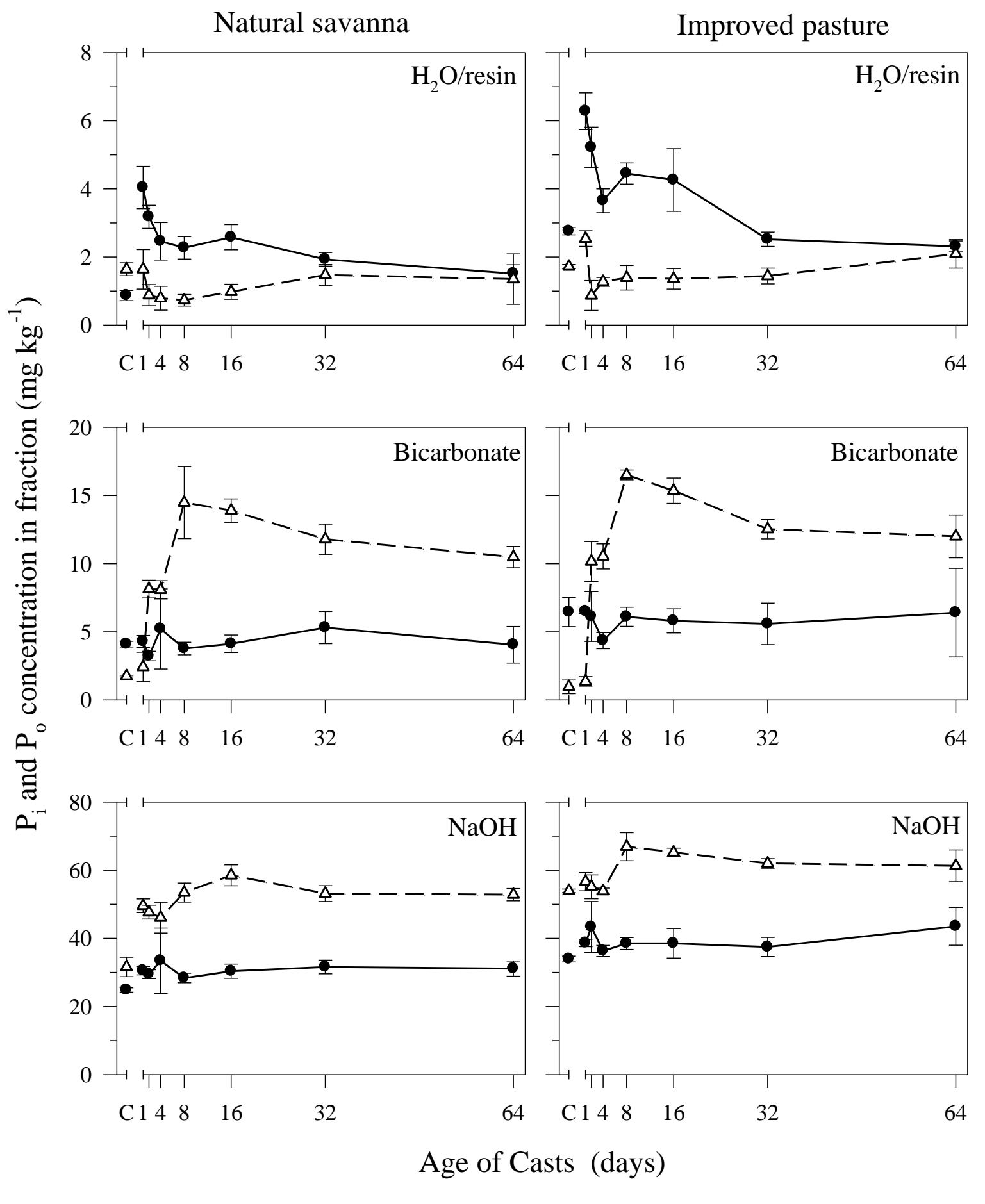

Figure 1

4 


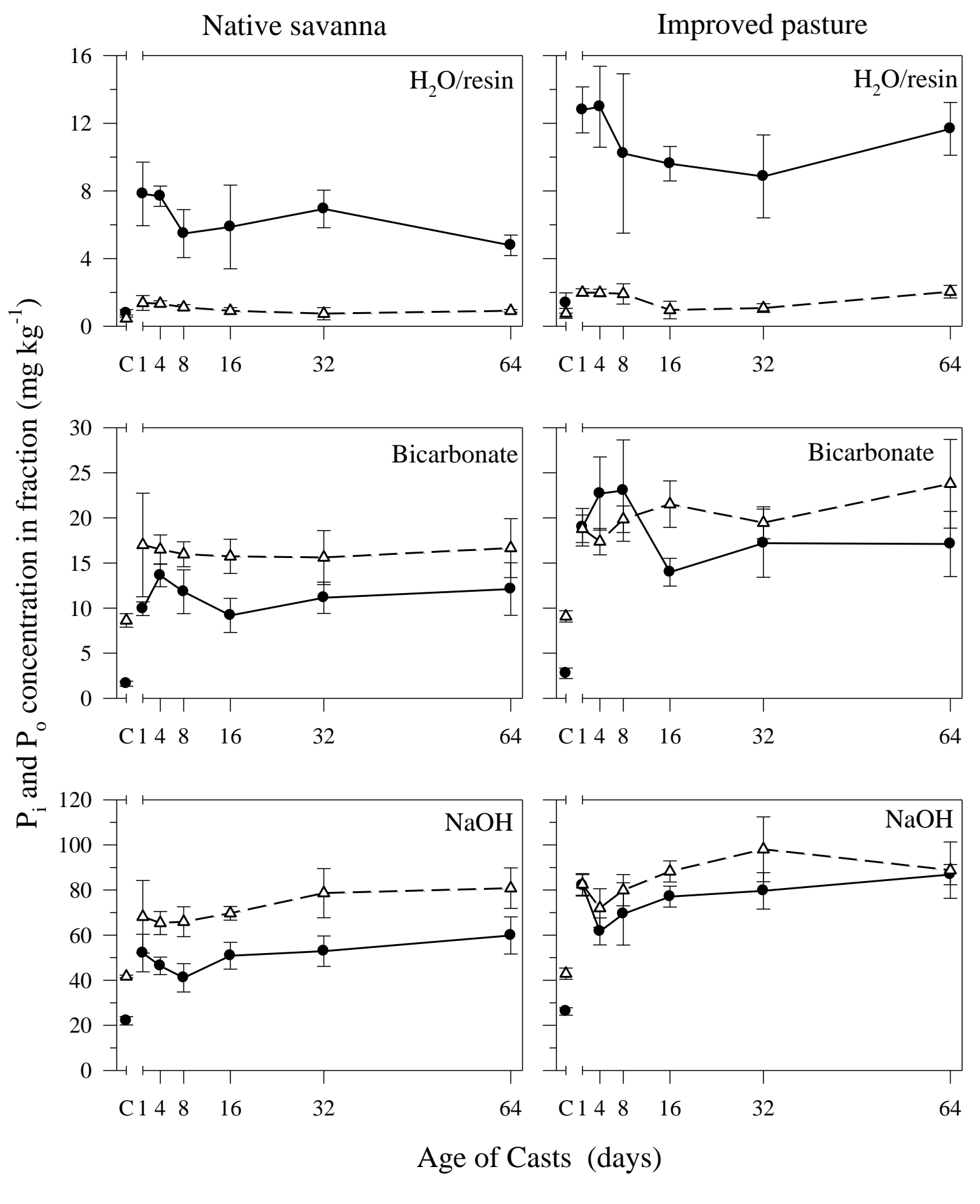

Figure 2 